\title{
Capital Flows and The Macro Economy: The Indian Experience
}

\author{
A.K.Seth \\ Sumati Varma
}

\begin{abstract}
This paper examines the macro-economic impact of capital flows into India. The variables identified in the study have been drawn on the basis of the transmission mechanism - to see how capital flows are transmitted into the economic system. To examine the issue the paper uses simple regression and Granger's Error Correction technique, which analyses long run and short run impact together. It has been found that out of the macro variables selected almost all are influenced by capital flows and represent the monetary environment of the economy.
\end{abstract}

Keywords: capital flows, transmission mechanism

The Indian economy embarked on a program of financial liberalisation in 1991, which led among other things to acceleration in capital flows and a distinct change in the financing of these flows. The neo-classical view of long term capital flows is based on the IMF's Financial Programming model (Khan and Haque 1990), which advocates capital inflows on the grounds of raising domestic investment through increased foreign savings, dampening the effects of exogenous shocks and promoting efficiency via transfer of technology and financial skills. The case for short term capital mobility is based on the "Efficient Market Hypothesis" which posits that current market prices of financial assets embody rationally all the known information about prospective returns from the asset. This theoretical hypothesis has stimulated a keen interest in understanding the nature and economic effects of capital flows as well as the appropriate policy responses to safeguard against financial instability that appears to be associated with international capital mobility. These issues are significant for India as it has gradually opened its capital account as part of a broader financial liberalisation strategy and is constantly pressurised to move on the path of full capital account convertibility.

Capital flows affect a wide range of economic variables such as exchange rates, interest rates, foreign exchange reserves, domestic monetary conditions as well as savings and investment. Capital flows into India have undergone a marked change in both quantum and type. Prior to 1991 capital flows were mainly in the form of aid and borrowings, but after 1991 this has been replaced by FDI and portfolio flows. This paper examines the impact of these flows on key macro-economic variables and the implications this has for economic policy.

\section{Review of Literature}

Various studies have examined the impact of capital flows on the economy in a developing country context. Calvo, Leiderman and Reinhart (1993), Corbo and Hernandez (1994) and Khan and Reinhart (1995) document the pattern and impact of capital flows for various countries of Latin America and East Asia. They explain this phenomenon in terms of the fall in US interest rates between 1989-92, combined with cyclical recession in the 
US, Japan and other parts of Europe that drove world capital to developing countries in search of higher returns. An alternative viewpoint offered by authors such as Chuhan, Claessens and Mamingi (1993), Hernandez and Rudolph (1995) highlight the role of "internal" or "pull" factors such as credible economic reforms, improved macroeconomic performance and domestic policies that encouraged investor confidence and attracted foreign investment. Bohn and Tesar (1998) assess the role of local versus global "push" factors in this context and find that the former was relatively more important in determining US investments in Asian markets. Calvo, Leiderman and Reinhart (1993) and Edwards (1999) have explored the association between capital inflows and real exchange rates for Latin America and found substantial evidence that capital inflows contributed to both real exchange rate appreciation and reserves' accumulation. Agenor and Hoffmaister (1988) have studied the macro-economic effects of capital inflows on short term fluctuations of the real exchange rate in a fixed or pre-determined exchange rate regime. Kamin and Wood (1998) examine the impact of capital flows upon monetary growth. They conclude that there is a significant independent effect of capital flows on domestic money demand for Mexico and the Pacific countries. Both reserve changes and net capital inflows tended to lower interest rates and raise M2, particularly for Mexico. Spiegel (1995) gives an account of sterilization methods and experience in Asia and Acharya (1999) has undertaken a similar exercise in the Indian context. Rangarajan (2000), Reddy (2005), Mohan (2007) and Nachane and Raje (2007) have extensively discussed the problems confronting monetary policy in the wake of capital inflows.

\section{Capital Flows and the Transmission Mechanism}

\section{Money Supply}

Capital flows affect the domestic money supply through the accumulation of net foreign currency assets with the central bank. Whether the monetary base is altered or not depends upon whether the central bank intervenes to maintain a level of exchange rate or allows it to float freely with no intervention. If there is intervention, then an accumulation of international reserves represents an increase in the net foreign exchange assets of the central bank and directly affects the monetary base.

$\mathrm{M}^{\mathrm{S}}=\mathrm{m} * \mathrm{H}$

Where ' $\mathrm{H}$ ' is high powered money (NDA + NFA) or monetary base, and ' $\mathrm{m}$ ' is the money multiplier.

$\mathrm{dM}^{\mathrm{S}}=\mathrm{dm} * \mathrm{H}+\mathrm{m} * \mathrm{dH}$

i.e. change in money supply depends on change in multiplier and change in monetary base. Now

$\mathrm{dH}=\mathrm{dNDA}+\mathrm{dNFA}$

$\mathrm{dNFA}=\mathrm{e}^{*} \mathrm{dRES}$ where $\mathrm{e}^{*}=$ exchange rate, $\mathrm{RES}=$ foreign asset reserves.

RES $=\mathrm{CA}+\mathrm{KA}$ where $\mathrm{CA}=$ current account, $\mathrm{KA}=$ capital account.

Putting the value of_RES we have

$\Delta \mathrm{mS}=\_\mathrm{m}(\mathrm{H})+\mathrm{m}(\overline{\mathrm{dNDA}}+\mathrm{eCA}+\mathrm{eKA})$

Neo classical demand function for money is given by:

$(\mathrm{M} / \mathrm{P})^{\mathrm{d}}=\mathrm{A} \mathrm{y}^{*} \mathrm{e}^{\mathrm{r}-}$

If $\mathrm{M}^{\mathrm{S}}=\mathrm{M}^{\mathrm{d}}=\mathrm{M}$ 
then the money demand function is given by

$\log \mathrm{M}=\log \mathrm{A}+\cdot \log \mathrm{Y}-\mathrm{r}_{-}+\log \mathrm{P}$

$\mathrm{dM} / \mathrm{M}=\cdot+\mathrm{dy} / \mathrm{y}+\mathrm{dP} / \mathrm{P}-\left({ }_{-} \mathrm{dr} / \mathrm{dM}\right) * \mathrm{dM}$

Equation (1) and (2) show that capital flows by changing $\mathrm{M}$, influence reserves, exchange rate, interest rate and the real sector, through inflationary expectations and the interest rate. Thus capital flows affect a wide range of variables, in both the financial and real sectors of the economy. This study therefore looks at the impact of capital flows on exchange rate movements, reserve accumulation, interest rate, imports, exports and price levels.

\section{Exchange rate movements}

Exchange rate is indicative of the economy's external competitiveness and a reflection of its balance of payments position. Exchange rate fluctuations have a widespread influence on the economy and can lead to crisis in the banking and financial sectors of the economy if they are excessive and sudden.

An inflow of capital causes the exchange rate to appreciate and real domestic interest rates to decline. This in turn leads to a decline in exports and domestic saving and an increase in imports and domestic investment. This raises the level of domestic expenditure in the economy, through changes in aggregate demand. The price-adjustment process then leads to a reallocation of resources from tradable to non-tradable goods and a switching of expenditures in favour of non-tradable. The rise in aggregate expenditure also increases the demand for tradable, leading to a rise in imports and a widening the trade deficit.

The transmission channel of the real exchange rate appreciation will however, depend on the exchange rate regime. With a floating exchange rate and no central bank intervention, an appreciation takes place through a nominal appreciation, but in a fixed exchange rate regime, the appreciation will work through an expansion in the domestic money supply, aggregate demand and the prices of non-tradable.

The impact of capital inflows on the real exchange rate depends on the composition of these flows. If capital flows into the economy in the form of portfolio investment rather than FDI, it leads to an increase in consumption expenditure rather than investment. If a large part of this increase is in the form of expenditure on non-tradable, this in turn causes a real exchange rate appreciation.

India has had a market-determined exchange rate since 1993, but the flexibility permitted by the monetary authority has been limited. However, since the rupee became convertible in 1991, the size and scale of intervention by the central bank has increased substantially. In order to avoid the instability associated with volatile capital flows the RBI intervenes both directly and indirectly through the use of quantitative restrictions, reserve requirements and interest rate policy.

\section{Exports and Imports}

The effect of capital flows on exports and imports depends on the exchange rate regime. If the exchange rate is fixed, capital flows through an increase in money supply cause inflation. The rise in domestic production costs has an adverse impact on exports and a favorable one on imports, widening the trade deficit. If the exchange rate is floating, an inflow of capital leads to a real exchange rate appreciation eroding the competitiveness of 
domestic production, crowding out exports and increasing the demand for imports.

\section{Foreign Exchange Reserves}

Capital inflows can be traced to either international reserves accumulation or a current account deficit, depending on the exchange rate regime. If there is no intervention by the central bank, then the net increase in capital assets via capital inflows would be associated with a similar increase in imports and therefore a widening current account deficit. Alternately, if the exchange rate regime is fixed and the central bank intervenes to counter appreciation pressures, then capital inflows would be visible as an increase in foreign exchange reserves. Since the two extremes are rarely observed in practice, the choice of intervention, or its size, narrows down to the degree of exchange rate flexibility desirable by the authorities and is, in essence, a policy choice.

\section{Interest rates}

An increase in the inflow of capital increases the availability of foreign exchange and savings to the economy. As a result of this the exchange rate appreciates and real domestic interest rates decline. The decline in interest rates is reflected in the entire portfolio of assets and in money demand. An increase in foreign exchange reserves leads to an increase in reserve money and increased money supply. Thus part of the increase in money supply will be offset by the increase in money demand, while the remaining part could raise inflation. The latter will, by bringing about real appreciation of the currency, reduce the extent of nominal appreciation. There is thus a trade-off between nominal appreciation and inflation. A free float would result in a sharp nominal and real appreciation. If the increase in flows is short term, this would be followed by gradual nominal depreciation. Though there would be changes in relative prices, average inflation effects would be moderate and no sterilization is required for short term flows. The nominal appreciation and increased exchange rate volatility can have negative effects on exports. If the exchange rate is kept fixed, reserves would accumulate leading to an increase in money supply and inflation. Sterilization measures to offset this will reduce inflationary pressures at the cost of higher interest rates and lower investment and growth.

\section{Stock Markets}

Capital flows in the form of portfolio investment leads to international portfolio diversification. This reduces risk and the cost of capital. An increase in financial flows also leads to improved liquidity and market depth and an increased efficiency in the allocation of investment. Increased linkages between domestic and foreign markets however, can also be associated with increased volatility of flows, which can have a destabilizing effect if domestic financial markets are thin.

\section{Income and Growth}

Capital flows affect both the real and the financial sectors of the economy. An increase in the inflow of capital increases the availability of foreign exchange causing the exchange rate to appreciate. This in turn reduces exports and domestic saving and increases imports and domestic investment. To the extent that imports replace domestic products, it 
leads to unemployment and idle capacity. Besides this, substantial reductions in real wages may be required to keep domestic products competitive if imports are readily available, especially if the quality of domestic products is not comparable with those from abroad. This reduces domestic income with multiplier effects on domestic output. This problem can be overcome by making the currency convertible at an exchange rate that makes imports sufficiently expensive to give domestic producers enough time to orient themselves towards global competition.

Increased capital mobility leads to growth in the economy through increases in output and also through increased efficiency of capital and labor. Growth therefore is the result of both increased investment and increased total factor productivity. The impact of capital mobility on growth largely depends on the composition of capital flows. If capital flows into the economy consist of portfolio flows rather than FDI, then growth does not overtly manifest itself through increases in investment. Even when capital comes in the form of FDI, the advantages of improvements in technology, better managerial practices and better governance lead to growth through "soft factors".

\section{Research Methodology}

Specification of the Models: In this study, naïve (simple) linear regression and the partial adjustment framework has been used. An inflow of capital has an impact on different macro variables. In this paper these macro variables have been taken as the dependant variable and capital flow as an independent variable. A linear regression is then established in a partial adjustment framework. The general specification of the model is done on the basis that the change in variable depends on the capital inflow and the expected nature of the variable.

$\mathrm{V}=\mathrm{f}(\mathrm{C}, \mathrm{E}(\mathrm{V}))$

The desired level of the variable is given as

$\mathrm{V}^{*}={ }_{-}+\mathrm{C}$

We assume that the current level of change in the exchange rate adjusts to the desired level.

We can write

$\mathrm{XR}={ }^{+}+{ }^{+} \mathrm{C}^{\mathrm{t}}+\mathrm{XR}_{\mathrm{t}-1}$
Where

Here - is the speed of adjustment of $\mathrm{XR}_{\mathrm{t}-1}-\mathrm{XR}_{\mathrm{t}}$. $=\ldots$ and $\ldots$

We have also estimated certain models in the naïve form where we have made changes in macro-economic variables a function of capital inflow. Lagged independent variables have also been used in some of the equations to introduce adaptive expectations.

The models estimated are as follows:

$$
\begin{aligned}
& \mathrm{ER}=\mathrm{a}+\mathrm{a} \mathrm{C}+\mathrm{a} \mathrm{C}+\mathrm{a} \mathrm{XR} \\
& E R=b+b^{t} C+{ }^{t} b^{t-1} C^{3} \ldots \ldots \ldots \\
& \overline{\mathrm{XP}} \stackrel{\mathrm{t}}{=} \mathrm{c}+\mathrm{c} \mathrm{C}^{-}+{ }^{\mathrm{t}} \mathrm{c} \mathrm{C}^{-}+{ }^{\mathrm{t}-1} \mathrm{EXP} \\
& \mathrm{XP}={ }^{0} \mathrm{~d}+{ }^{1} \mathrm{~d}^{\mathrm{t}} \mathrm{C}+{ }^{2} \mathrm{~d}^{1} \mathrm{C}^{3}{ }^{\mathrm{t}-1} \\
& \overline{I M P}^{\mathrm{t}}=\mathrm{e}^{0}+\mathrm{ec}^{1-} \mathrm{C}^{\mathrm{t}}+\mathrm{e}^{2-\mathrm{C}} \text { 草1 } \mathrm{e} \text { IMP } \\
& \text { IMP }=\mathrm{f}+\mathrm{f}^{1} \mathrm{C}^{\mathrm{t}}+\mathrm{f}^{\mathrm{t}-\mathrm{C}}{ }^{3} \mathrm{t}^{\mathrm{t}-1} \\
& \bar{R} E S \stackrel{t}{=} g{ }^{0}+g^{1} \bar{C}+g^{t} C^{-}+t^{t-1} \text { RES } \\
& -\operatorname{RES}{ }_{\mathrm{t}}=\mathrm{h}_{0}+\mathrm{h}_{1}{ }_{-}^{\mathrm{t}} \mathrm{C}_{\mathrm{t}}+{ }^{2} \mathrm{~h}_{2-}^{\mathrm{t}-1} \mathrm{C}_{\mathrm{t}-1}^{3}
\end{aligned}
$$




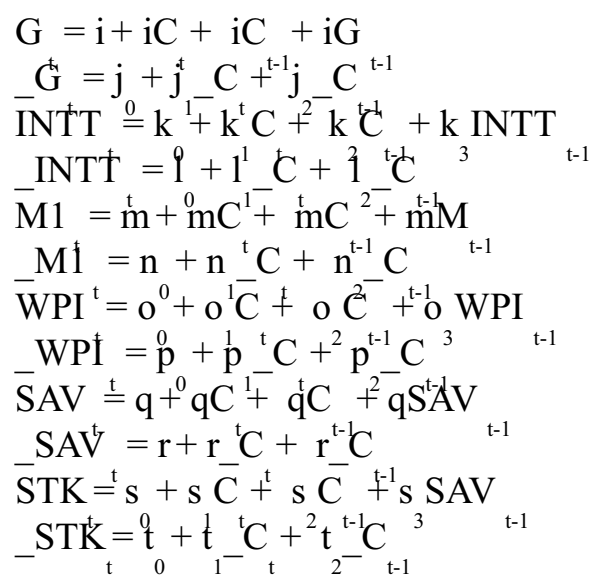

Where $\mathrm{ER}=$ exchange rate, $\mathrm{C}=$ net capital flow, $\mathrm{M} 1=$ money supply, WPI $=$ wholesale price index, $\mathrm{CPI}=$ consumer price index, $\mathrm{XP}=$ exports, $\mathrm{IMP}=$ imports, $\mathrm{RES}=$ reserves, $\mathrm{G}$ $=$ output, $\mathrm{INTT}=$ interest rate and $\mathrm{SAV}=$ savings.

Data Sources: Data for the study has been taken from International Financial Statistics (IFS), RBI's Handbook of Statistics for the Indian Economy and RBI's Database on the Indian Economy from the RBI website for the period 1991- 2005. The data for exchange rate, exports, imports CPI and WPI have been taken from line 70, 71 and 63 of IFS respectively. Data for capital flows, interest rates, M1, trade and reserves have been taken from Table 199, 179, 172, 197 and 205 of the Handbook of Statistics for the Indian Economy and for stock markets from the BSE Handbook.

\section{Estimation and Results}

\section{Procedure}

The time series properties of the variables in the study are examined to see if the mean and variance of the series is independent of time over the sample period. If the series exhibit I(1) behaviour, a natural corollary concerns whether the time series display co- integration i.e. if there exist linear combinations of these series that are stationary.

Time Series Properties: Stationary test of variables is a pre-requisite for the analysis of cointegration. For this purpose we may use the unit root tests for levels and for the first and higher order differences of the variables. Various tests - the Dickey Fuller, Augmented Dickey Fuller (ADF), Phillips Perron (PP) and Durbin Watson (Sargan and Bhargava), are available to test the order of integration. This paper uses the ADF and PP test for establishing the order of integration. In order to have a meaningful regression the order of integration of the dependant variable should be greater than or equal to the order of integration of the independent variable. The Durbin Watson/Durbinh test was used to check for serial correlation in the residuals. Since some of the models use lagged dependant variables the Durbin Watson test is likely to give biased estimates and an alternate test, Durbinh is more appropriate.

Co-integration Analysis: If the series exhibit I(1) behavior, it becomes necessary to test for cointegration to estimate whether the series exhibit a long run equilibrium relation even though they may drift apart in the short run. Engle and Granger (1987) proposed a two step 
procedure for inferring the existence of a linear combination and for estimating a basis vector. Choosing an arbitrary normalization, the procedure consists in the first stage OLS regression of one variable against the other. The estimated coefficient vector of this regression then gives the basis of the cointegrating space. The test for cointegration is then based on the residual of this preliminary regression; if they still contain a unit root, the null hypothesis of non cointegration cannot be rejected. The second stage consists in the estimation of this corresponding error correction.

Testing for Causality: We use the bivariate Granger Causality test to examine the existence of a causal relationship between capital flows and other macroeconomic variables. The test involves estimating the following regressions:

$\mathrm{C}=-\mathrm{i} \mathrm{V}+\sum \mathrm{j} \mathrm{C}+\mathrm{u}$
$\mathrm{V}^{\mathrm{t}}=-\mathrm{H}_{\mathrm{i}} \mathrm{V}^{\mathrm{t}-1}+\sum \mathrm{j} \mathrm{C}^{\mathrm{t}-\mathrm{j}}+\mathrm{u}^{1 \mathrm{t}}$

Where it is assumed thät the disturbances $\mathrm{u}_{1 \mathrm{t}}$ and $\mathrm{u}_{2 \mathrm{t}}$ are uncorrelated.

\section{Results}

We applied the ADF and the PP to test unit roots in the series. Testing of unit root indicates that the variables considered in the regression are of zero order, therefore meaningful estimates can be drawn from the linear regression. The calculated test statistics along with their critical values are given in Table 1. The results indicate that the order of integration of the dependant variable is either equal to or greater than the order of integration of the independent variables. Therefore the regression results are meaningful and not spurious.

Table 1: Testing Order of Integration of Variables 1991:1- 2005:4

\begin{tabular}{|c|c|c|}
\hline Variables & $\mathrm{ADF}$ & $\mathrm{PP}$ \\
\hline $\mathrm{C}$ & $-4.559^{*}$ & $-38.788^{*}$ \\
\hline C & $-11.266^{*}$ & $-58.838 *$ \\
\hline $\mathrm{Y}$ & $-5.386 *(1$ lag trend $)$ & $-50.311 *(1$ lag trend $)$ \\
\hline${ }_{-} \mathrm{Y}_{\mathrm{t}}$ & $-11.316^{* * *}$ & $-56.749 *$ \\
\hline $\mathrm{XP}$ & NS & NS \\
\hline _XP & $-12.189^{*}$ & $-69.690^{*}$ \\
\hline IMP & NS & NS \\
\hline _IMP & $-6.504^{*}$ & $-36.174 *$ \\
\hline STK & $-2.728^{*}$ & $-10.810^{*}$ \\
\hline _STK & $-4.629 *$ & $-45.269^{*}$ \\
\hline WPI & NS & NS \\
\hline _WPI & $-6.183 *$ & $-39.230^{*}$ \\
\hline INTT & $-3.745^{*}$ & $-19.745^{*}$ \\
\hline _INT & $-13.223^{*}$ & $-68.793 *$ \\
\hline ER & NS & NS \\
\hline
\end{tabular}




\begin{tabular}{cll}
\hline ER & $-5.266^{*}(1$ lag trend $)$ & $-20.774^{*}$ \\
M1 & $-3.570^{*}(1$ lag trend $)$ & $-31.766^{*}$ ( 1 lag trend $)$ \\
-M1 & $-10.893^{*}$ & $-58.088^{*}$ \\
SAV & NS & NS \\
_SAV & $-3.762 * *($ lag trend $)$ & $-16.598^{* * *}$ \\
RES & $-13.912 \mathrm{I}(2)$ & $-65.002 \mathrm{I}(2)$ \\
RES & $\mathrm{NS}$ & $\mathrm{NS}$ \\
\hline
\end{tabular}

DF Critical Value (0 lag) at $1 \%:-3.709,5 \%-2.983,10 \%-2.623$

(1 lag trend) at $1 \%:-4.150,5 \%-3.500,10 \%-3.180$

PP Critical Value (0 lag) at 1\%:--18.972, 5\%-13.332, 10\%-10.724

(1 lag trend) at $1 \%:-25.836,5 \%-19.872,10 \%-16.856$

Table 2: Speed of adjustment of Variables affected by Capital Flow

\begin{tabular}{ll}
\hline Variables affected by Capital Flow & Speed of Adjustment \\
\hline ER & 2.7 \\
ER & 10 \\
XP & 2 \\
XP & 2.63 \\
IMP & 2.5 \\
STK & 3 \\
WPI & 2 \\
INTT & 1.35 \\
Y & 2 \\
M1 & 10 \\
RES & 1.14 \\
\hline
\end{tabular}

The following regression equations capture the impact of capital flows on the foreign exchange market, wherein capital inflow and expected capital inflow have been taken as explanatory variables and the trend variable ' $t$ tt' has been used to capture omitted variables. Since the exchange rate is measured in direct quotes (Rs/\$) therefore the capital inflow would have an appreciating effect as is shown by the regressions. Equations 25 and 26 also show that expected capital flows are significant determinants of levels as well as changes in exchange rate.

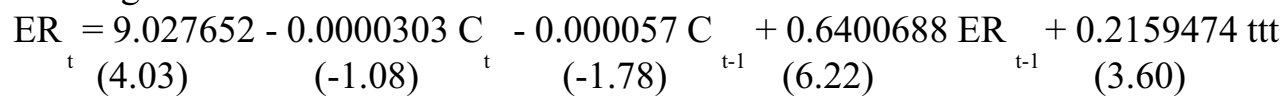

$$
\mathrm{R}_{-}=0.9873 \quad \text { Adj } \mathrm{R}_{-}=0.9860 \quad \text { Durbinh }=.3969137
$$

$$
{ }_{-} \overline{E R}_{t}=1.44999-0.0000361 \mathrm{C}-0.0000496 \mathrm{C}_{\mathrm{t}-1}+0.9963603 \mathrm{XR}_{\mathrm{t}-1}
$$


$\mathrm{R}_{-}=0.9849 \quad$ Adj $\mathrm{R}_{-}=0.9840 \quad$ Durbinh $=.1001208$

Capital flow to a particular economy also has an impact on exports. Capital flows into the economy in the form of FDI and Portfolio investment. If it flows in the form of FDI, it increases the productive capacity of the economy and portfolio flows create performance expectations in the industrial sector. Capital flows and expected capital flows have therefore been used as explanatory variables for levels of exports in equations 27, 28 and 29. $\mathrm{XP}_{\mathrm{t}}=2515.001+.1116918 \mathrm{C}+.48928 \mathrm{EXP}+532.7767 \mathrm{ttt}$

$$
\begin{aligned}
& \text { (2.78) } \\
& (1.58)^{\mathrm{t}} \quad \text { (3.82) } \\
& R_{-}=0.9759 \quad \text { Adj } R_{-}=0.9742 \quad \text { Durbinh }=-.5993273 \\
& \mathrm{XP}_{\mathrm{t}}=\underset{(1.37) \quad 38.70129+.0071889 \mathrm{C}+.70243 \mathrm{EXP}}{(3.81)^{\mathrm{t}}}\left(\begin{array}{c}
\mathrm{E} \\
(9.59)^{\mathrm{t}-1}
\end{array}\right. \\
& \mathrm{XP}_{\mathrm{t}}=24.23514+.0061232 \mathrm{C}+.0058436 \mathrm{C}{ }_{(0.91)}+.6231977 \mathrm{EXP}{ }_{\mathrm{t}-1}
\end{aligned}
$$
$\mathrm{R}_{-}=0.8161$
Adj $R_{-}=0.8046$
Durbinh $=-0.1547654$

Equations 27 to 29 indicate that capital flows are important determinants of level and change in exports via availability of resources with exporters. The speed of adjustment for level exports is one and a half years and that the speed of adjustment in exports is approximately three years.

$$
\mathrm{IMP}_{\mathrm{t}}=\underset{(1.08)}{891.0035}-0.247584 \mathrm{C}-0.1429678 \mathrm{C}+1.050252 \mathrm{IMP}
$$

$$
\mathrm{R}_{-}=0.9832 \quad \text { Adj } \mathrm{R}_{-}=0.9820 \quad \text { Durbinh }=.0506864
$$

$\mathrm{IMP}=2239.721-0.203173 \mathrm{C}-0.1803871 \mathrm{C}_{\mathrm{t}-1}+0.6291882 \mathrm{IMP}+564.8529 \mathrm{ttt}(31)$
(2.71)
$(-0.31)$
$(-2.49)$
(5.20)

$\mathrm{R}_{-}=0.9871 \quad$ Adj $\mathrm{R}_{-}=0.9859 \quad$ Durbinh $=.4327836$

In case of imports, equations 30 and 31 , show the significance of expected capital flows, but the term has obtained a negative sign. This indicates the diluting impact that capital inflows have on imports because of product substitution (FDI) and enhancing performance expectations (FPI). The speed of adjustment to the desired level is approximately two and a half years.

$\mathrm{STK}_{\mathrm{t}}=329.1664+.0104768 \mathrm{C}+.7495868 \mathrm{STK}{ }_{\mathrm{t}-1}$

$$
\mathrm{R}_{-}=0.7273 \quad \text { Adj } \mathrm{R}_{-}=0.7149 \quad \text { Durbinh }=.1479814
$$

$\mathrm{STK}_{\mathrm{t}}=315.8944+.014 \overline{4} 74 \mathrm{C}+0.0081124 \mathrm{C}+0.7667369 \mathrm{STK}_{\mathrm{t}-1}-4.475892 \mathrm{ttt}$ (33)
(2.67)
$\left(2.12^{\dagger}\right)$
$(1.05)^{t-1}$
(8.13)

\section{$\mathrm{R}_{-}=0.7369 \quad$ Adj $\mathrm{R}_{-}=0.7118 \quad$ Durbinh $=.0986896$}

Equations 34 and 35 explain more than $71 \%$ variation in stock prices. Prices of stocks are also affected by capital flows. They adjust to their desired levels in approximately four years.

$$
\mathrm{SAV}_{\mathrm{t}}=\underset{(-0.01)}{-223.4566}-12.37155 \Delta \mathrm{C}_{\mathrm{t}}-10.27911 \Delta \mathrm{C}_{\mathrm{t}-1}
$$

$\mathrm{R}_{-}=0.2102 \quad$ Adj $\mathrm{R}_{-}=0.1735 \quad \mathrm{DW} \mathrm{Stat}=1.193709$

$-\overline{\mathrm{SAV}}_{\mathrm{t}}=100981.3-11 . \overline{4} 9892 \Delta \mathrm{C}_{\mathrm{t}}-10.32422 \Delta \mathrm{C}_{\mathrm{t}-1}-4012.744 \mathrm{ttt}$ 


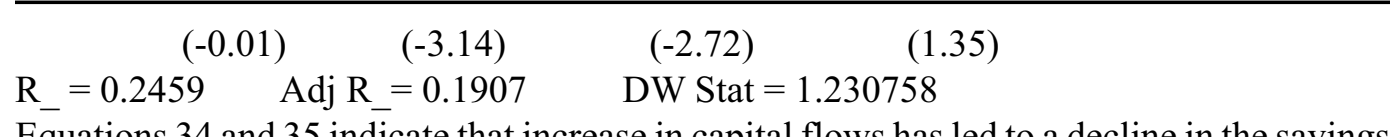

Equations 34 and 35 indicate that increase in capital flows has led to a decline in the savings rate in the economy. This is because foreign savings have had a crowding out effect on domestic savings.

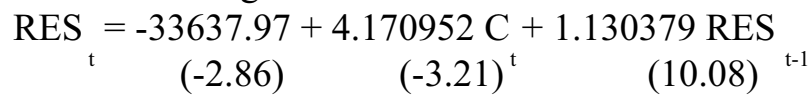

$$
\begin{aligned}
& \mathrm{R}_{-}=0.8432 \quad \text { Adj } \mathrm{R}_{-}=0.8360 \quad \text { Durbinh }=0.56631933 \\
& \mathrm{RES}_{\mathrm{t}}=17786.7+4.930645 \mathrm{C}+2.254406 \mathrm{RES}-6623.906 \mathrm{ttt}
\end{aligned}
$$

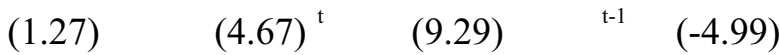
$\mathrm{R}_{-}=0.9007$
Adj $R_{-}=0.8937$
Durbinh $=-.3965412$

Equations 36 and 37 indicate that reserves have increased as a consequence of capital flows. This shows sterilization of capital flows by the central bank to maintain exchange rate at a competitive level.

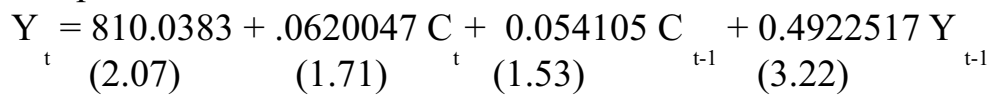
$\mathrm{R}_{-}=0.5506$
Adj $R_{-}=0.5178$
Durbinh $=-.4574918$

Equation 38 indicates that capital flows are significant determinants of income. Expected capital flows are significant at $10 \%$ level of significance. The actual levels of real income adjust to desired levels in approximately one and a half years. The regression explains more than $50 \%$ variation in the dependant variable.

$$
\begin{aligned}
& \text { WPI }=1.822202-0.0000476 \mathrm{C}+0.9977386 \mathrm{WPI} \\
& \text { (2.70) } \quad(-1.96) \quad{ }^{\mathrm{t}}(106.98) \\
& \mathrm{R}_{-}=0.9975 \quad \text { Adj } \mathrm{R}_{-}=0.9974 \quad \text { Durbinh }=0.0908275 \\
& \mathrm{WPI}_{\mathrm{t}}=11.03999-0.0000517 \mathrm{C}_{\mathrm{t}}+0.8189969 \mathrm{WPI}+.2208681 \mathrm{ttt} \\
& (-2.23)^{\mathrm{t}}(10.69)
\end{aligned}
$$

$$
\mathrm{R}_{-}=0.9978 \quad \text { Adj } \mathrm{R}_{-}=0.9976 \quad \text { Durbinh }=0.2313972
$$

Capital flows are significant determinants of WPI with a negative sign. This reflects that capital flow in India has led to greater productivity, thereby having a depressing effect on price levels. The speed of adjustment of actual level to the desired level is approximately five years.

$$
\begin{aligned}
& \text { INTT }=9.104201-0.0000258 \mathrm{C}-0.002427 \mathrm{C}+0.3621002 \mathrm{INTT}
\end{aligned}
$$

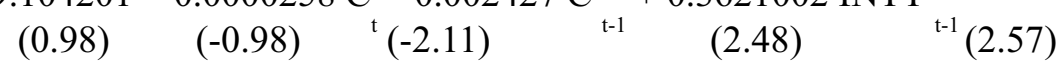

$$
\mathrm{R}_{-}=0.3638 \quad \text { Adj } \mathrm{R}_{-}=0.3194 \quad \text { Durbinh }=-0.6346786
$$

Equation 41 shows that capital flows have an adverse impact on the interest rate (loanable fund theory). The increase in money supply has increased loanable funds thus softening the interest rate. Interest rate adjusts to the desired level in a year and a quarter.

$$
\mathrm{M} 1_{\mathrm{t}}=7608.884+0.6344789 \mathrm{C}_{\mathrm{t}}+1.996454 \mathrm{C}_{\mathrm{t}-1}+0.9054123 \mathrm{M} 1_{\mathrm{t}-1}
$$

\section{$\mathrm{R}_{-}=0.9467 \quad$ Adj $\mathrm{R}_{-}=0.9430 \quad$ Durbinh $=-0.4915107$}

Equation 42 explains $94 \%$ variation in money supply. The equations show the significance of expected capital flows. Money supply adjusts to its desired level in 10 years. This implies that the impact of capital flows on money supply reaches with a lag. Having postulated the relationships between various macro variables and capital flows, an aspect of the rela- 
tionship that still needed to be explored was whether causation existed among the variables. To ascertain causation the Granger causality test was applied to test for causality and reverse causality. The results of the Granger causality test are given in Table 3. The indicators given by the test are given in the last column.

Table 3: Testing for Granger Causality 1991:1 -2002:4

\begin{tabular}{|c|c|c|c|}
\hline Null Hypothesis & F-Statistics & Probability & Causality \\
\hline ER does not granger cause $\mathrm{C}$ & 1.184423 & .281 & \multirow[t]{2}{*}{ Capital flows _ Exchange rate } \\
\hline C does not granger cause ER & 8.8633702 & .0043 & \\
\hline $\mathrm{G}$ does not granger cause $\mathrm{C}$ & .05797799 & .811 & \multirow[t]{2}{*}{ Capital flows__Growth } \\
\hline $\mathrm{C}$ does not granger cause $\mathrm{G}$ & 7.9647774 & .0067 & \\
\hline INTT does not granger cause $\mathrm{C}$ & 1.8690773 & .177 & \multirow[t]{2}{*}{ Capital flows_Interest rate } \\
\hline C does not granger cause INTT & 4.445496 & .040 & \\
\hline WPI does not granger cause $\mathrm{C}$ & 3.0355077 & .087 & \multirow[t]{2}{*}{ Capital flows_WPI } \\
\hline C does not granger cause WPI & 12.003391 & .0001 & \\
\hline STK does not granger cause C & .25165897 & .618 & \multirow[t]{2}{*}{ Capital flows_Stock Prices } \\
\hline C does not granger cause STK & 9.0952885 & .0039 & \\
\hline $\mathrm{XP}$ does not granger cause $\mathrm{C}$ & 4.527458 & .038 & \multirow[t]{2}{*}{ Export_Capital Flows } \\
\hline C does not granger cause XP & 2.3455907 & .131 & \\
\hline IMP does not granger cause $\mathrm{C}$ & .15451627 & .696 & \multirow{2}{*}{ Capital flows__Imports } \\
\hline C does not granger cause IMP & .35086012 & .556 & \\
\hline M1 does not granger cause $\mathrm{C}$ & .048579 & .826 & \multirow{2}{*}{ Capital flows_M1 } \\
\hline $\mathrm{C}$ does not granger cause M1 & 13.072629 & .00066 & \\
\hline SAV does not granger cause $\mathrm{C}$ & .26283342 & .610 & \multirow[t]{2}{*}{ Capital flows__Savings } \\
\hline C does not granger cause SAV & 22.039038 & .000019 & \\
\hline RES does not granger cause $\mathrm{C}$ & 1.398054 & .247 & \multirow[t]{2}{*}{ Capital flows_Reserves } \\
\hline C does not granger cause RES & 20.091237 & .000039 & \\
\hline
\end{tabular}

\section{Conclusion}

The empirical analysis in this paper indicates that capital flows have had a significant impact on the macroeconomic environment in India in the post liberalization period. Capital flows have emerged as a significant explanatory variable of almost all financial and real variables that have been examined. This has clear policy implications for the management of capital inflows.

A variety of monetary and fiscal policy measures have been used to handle the deluge of capital flows making its way into the economy. The central bank has been intervening in the forex market to buy dollars, causing a surge of liquidity in the domestic system with implications for inflation management. Along with the finance ministry it has imposed restrictions on inflows of external commercial borrowings and simultaneously eased controls on the outflows of funds from the domestic economy. The unremunerated reserve requirements of banks have been raised along with the sale of securities to suck out excess liquidity from the system.

On the fiscal front there have been two packages of incentives for exporters including lowering the interest rate for export credit to offset the effects of the appreciating rupee. 
The recent controls on participatory notes announced by SEBI are also a part of the same policy framework.

The Indian experience with capital flows is an example of the famous "impossible trinity" according to which it is impossible to simultaneously pursue an independent monetary policy, exchange rate stability and full capital mobility. Monetary policy in India follows the multiple indicators approach, unlike some other countries which pursue either an inflation target or a currency value target. The RBI in contrast focuses on overall economic growth and price stability setting targets for both credit growth and money supply growth.

\section{References}

Acharya S (1999) "Managing External Economic Challenges in the Nineties: Lessons for the Future", Paper presented at ICRIER, New Delhi.

Agenor Pierre-Richard and Alexander W. Hoffmaister (1998) "Capital Inflows and the Real Exchange Rate: Analytical Framework and Econometric Evidence" in Reuven Glick (ed) Managing Capital Flows and Exchange Rates - Perspectives From the Pacific Basin, Cambridge University Press.

Bohn, H., and L. Tesar, (1996), "U.S. Equity Investment in Foreign Markets: Portfolio Rebalancing or Return Chasing? American Economic Review, Vol 86, No. 2, pp. 77-81.

Calvo, A Guillermo, L Leiderman and C.M. Reinhart (1993) "Capital Inflows and Real Exchange Rate Appreciation in Latin America: The Role of External Factors", IMF Staff Papers, 40 (1), March, Washington D.C.

Chuhan, P., S Classens, and N. Mamingi, (1998) "Equity and Bond Flows to Latin America and Asia: The Role of Global and Country Factors," Journal of Development Economics, Vol.55, pp.439-63.

Corbo, V and L. Hernandez (1994), "Macroeconomic Adjustment to Capital Inflow: Latin American Style vs. East Asian Style", World Bank Policy Research Working Paper, 1377, World Bank, Washington D.C.

Dooley Michael and Donald Mathieson (1994) "Exchange rate Policy, International Capital Mobility and Monetary Policy Instruments," in Exchange Rate Policy and Interdependence, Perspective From the Pacific Basin, ed R Glick and M Hutchinson, Cambridge University Press.

Dooley Michael, Donald Mathieson, and L. Rojas-Suarez (1997) "Capital Mobility and Exchange Market Intervention in Developing Countries" NBER WP 6247, Cambridge, Massachusetts.

Engle, R.F., and C.W.J. Granger. (1987) “Co- integration and Error Correction Representation, Estimation and Testing”. Econometrica 55 (2):251-76.

Feldstein, Martin and Charles Horioka (1980) "Domestic Saving and International Capital Flows “Economic Journal, Vol. 90 (358), pp 314 - 29.

Glick, Reuven, and Ramon Moreno (1995), "Capital Flows and Monetary Policy in East Asia". In Monetary and Exchange Rate Management with International Capital Mobility: Experiences of Countries and Regions Along the Pacific Rim, Hong Kong Monetary Authority, pp. $14-48$.

Goldstein, Morris, D.J. Mathieson, and Timothy Lane. (1991). "Determinants and Sys- 
temic Consequences of International Capital Flows" IMF Occasional Paper 77. Washington D.C.

Hernandez L. and H Rudolf (1995) "Sustainability of Private Capital Flows to Developing Countries: Is a Generalized Reversal Likely" World Bank Policy Research Paper No 1518, Washington D.C.

Kamin, S.B. and P.R.Wood (1998) "Capital Inflows, Financial Intermediation and Aggregate Demand: Empirical Evidence from Mexico and other Pacific basin Countries" in R. Glick (ed) Managing Capital Flows and Exchange Rates - Perspectives From the Pacific Basin, Cambridge University Press.

Khan, M.S and C. M. Reinhart (1995) "Capital Flows in the APEC Region" IMF Occasional Paper, March, Washington D.C.

Khan, M.S and N U Haque (1990) "Adjustment with Growth: Relating the Analytical Approaches of the IMF and the World Bank", Journal of Development Economics, Vol 32(1), pp 155-79.

Kohli Renu (2001). "Capital Flows and their Macroeconomic effects in India" Indian Council for Research on International Economic Relations, Working Paper No 64, March, ICRIER, New Delhi.

Mohan R (2007) "Capital Account Liberalization and the Conduct of Monetary Policy: The Indian Experience", paper presented at a seminar on 'Globalization, Inflation and Financial Markets', Banque de France, Paris, France, June 14.

Nachane D M and N Raje (2007), "Financial Liberalization and Monetary Policy", Margin - The Journal of Applied Economic Research, Vol1(1), March, pp 47-83.

Patnaik, Ila (2003) “India's Policy Stance on Reserves and the Currency" Indian Council for Research on International Economic Relations, Working Paper No 108, September, ICRIER, New Delhi.

Patnaik, Ila (2003) “The Consequences of Currency Intervention in India” Indian Council for Research on International Economic Relations Working Paper No 114 , October, ICRIER, New Delhi.

Rangarajan, C (2000) "Capital Flows: Another Look", Economic and Political Weekly, Vol $X X X V(50)$, pp 4421-27.

Reddy, Y.V (2005):Annual Policy Statement for the Year 2004 -05, Reserve Bank of India. Speigel, M.M (1995) "Sterilization of Capital Inflows through the Banking Sector: Evidence from Asia", FBRSF Economic Review, 3.

Taylor M.P. and L. Sarno, (1997) "Capital Flows to Developing Countries: Long and Short Term Determinants" The World Bank Economic Review, Vol. 11, No 3, pp 451-70.

Tobin, J (1978): “A Proposal for International Monetary Reform”, Eastern Economic Journal, Vol 4 (July- October), pp 153-59. 